\title{
THE LITERARY INTERESTS OF CHICAGO. V
}

\author{
HERBERT E. FLEMING \\ University of Chicago
}

\section{V. ÆSTHETIC PERIODICALS OF THE WORLD'S FAIR CITY I890-I900}

"All this time there had been building the beautiful city of white palaces on the lake, and it was now open for the world to see what Chicago had dreamed and created. Although it had made me impatient to have $\mathrm{Mr}$. Dround spend on it his energy that was needed in his own business, now that it was accomplished, in all its beauty and grandeur, it filled me with admiration.

"There were few hours that I could spend in its enjoyment, but I remember one evening after my return from the East, when we had a family party at the Fair. May and Will were spending their vacation with us during the hot weather, and the four of us, having had our dinner, took an electric launch and glided through the lagoons beneath the lofty peristyle out to the lake, which was as quiet as a pond. The long lines of white buildings were ablaze with countless lights; the music from the bands scattered over the grounds floated softly out upon the water; all else was silent and dark. In that lovely hour, soft and gentle as was ever a summer night, the toil and trouble of men, the fear that was gripping men's hearts in the market, fell away from me, and in its place came Faith. The people who could dream this vision and make it real, those people from all parts of the land who thronged here day after day-their sturdy wills and strong hearts would rise above failure, would press on to greater victories than this triumph of beauty-victories greater than the world had yet witnessed!" E. V. Harrington, packer, in The Memoirs of an American Citizen, by Robert Herrick, I905.

Basking in a new light reflected over their trade city by the "White City" of the World's Columbian Exposition, the men attempting to publish periodicals at Chicago during the nineties opened their eyes to many new influences. First they adopted the appeal of pictorial art. The World's Fair was a magnificent picture. Graphic presentation was the form used to attract æsthetic interest in several journals begun just before, during, and after I893. The copper-plate half-tone did not come into 
general commercial use until that year. The cheapening of this process started the wave of popular illustrated magazines from other centers, which has since become an inundation. But in Chicago this turn toward emphasis on illustrations was quickened by the Fair, which even prosaic visitors from western prairie soil likened to the "heavenly vision." Men ambitious to be publishers went into ecstasies over its suggestions. In imagination they saw heaps of gold as the reward for publishing pictures, supplemented with literary material.

Besides the effect of the panorama, there was the finer influence from the exhibitions of the fine arts. The subtleties of architectural decoration, even though done in ephemeral staff; the grace of form from the hands of the great sculptors, although the statues were but casts; and, above all, the original paintings from the brushes of Old and New World masters, hanging in hall after hall of the Fine Arts Building, revealed to the people of Chicago and the West the beauty of universal art. Foreign members of the artist group inspired in their Chicago hosts enthusiasm for art in all of its manifestations; and the judging for awards stimulated the habit of criticism on the basis of merit, tending to suppress praise from local pride. Magazines devoted to the fine arts, and literary magazines edited in the spirit of the artist class, followed the Fair.

The World's Columbian Exposition also brought historic perspective to the new and still crude western metropolis. On one bright day during that summer the vessels from Chicago harbors were, as usual, marking the sky-line of the lake to the east with their clouds of smoke, the pennants of commerce. Three caravels, picturesque imitations of those in which Columbus had sailed to America in I492, and, like those of the discoverer, having come slowly over from old Spain, moved past the lake craft and into the Jackson Park lagoon, where they still stand moored today. These caravels, and the exposition in nearly all its sections, gave to the people of the new western market-metropolis the vivid impression that the life of their community is but a chapter in the epic of world-wide civilization. Nearly all the general literary and 
pictorial magazines established in Chicago during the Fair decade showed the effect of this impression.

Finally, for a season the World's Fair transformed Chicago the inland center into Chicago the cosmopolitan center. This city, being far from a seaport, normally cannot have in it a kaleidoscopic company of transients from all the world, such as assembles daily in New York, London, and Paris. But for the one brief summer the down-town streets and the wide ways at the Fair grounds were thronged with visitors, not merely from many localities of the United States, but from all countries. On the Midway Plaisance, a boulevard of the nations and races, bordered for a mile by groups of the natives of Europe and of the Orient in settings from their distant towns and villages, thousands of men and women from everywhere touched shoulders in one common interest. Not one of the seventy periodicals of æsthetic character undertaken in Chicago during the decade of this cosmopolitan gathering contained the word "western" in its title. In every period before this there had been "western" literary journals attempted at Chicago. But the World's Fair made for a breadth of view which repressed the western spirit. All types of literary and artistic periodicals became more cosmopolitan in their outlook, and in some of the general literary magazines of the decade unique efforts at the world-wide character were made. During the thirteen years since the exposition was a reality, the tradition of it has had a vital influence on Chicago. But, as with reading a novel, the effects are most vivid while one is going through its pages and just after the book is closed, so the enlarging influence of the World's Fair was felt most forcibly by Chicago publishers during the year of the Fair and immediately after the closing of its gates.

Illustrated journals, in form though not in periodicity like Harper's Weekly, were the most conspicuous of the mushroom periodicals at Chicago in the first few years of the World's Fair decade. In most publications illustrations are used to supplement literary features. In these journals material in printed form designed to give literary entertainment was used as an auxiliary 
to the illustrations. The most important of these periodicals were Halligan's Illustrated World's Fair, Campbell's Illustrated Columbian, and the Graphic.

The first number of Halligan's Illustrated World's Fair, put out for promotion, appeared in I89o. Mr. Jewell Halligan, its originator, came to Chicago from Denver, and in this advance issue announced plans for a most pretentious publication. The second number was published in August of the next year, and the periodical was issued monthly until December, I893.

"To carry the undeniable news of the eye to the ends of the earth," was one phase of the publishing policy announced by Halligan's paper. Its pages were of unusually large size. Most of them were filled with half-tone illustrations. An advertisement, in I893, said that the magazine was "the first to exclude all other forms of picture save photographs on copper called half-tones." Undeniably the illustrations, done by the new process and printed on extra-fine paper, were well executed. The journal's pictorial record of the Fair was so complete that two editions of extra copies were printed for sale in bound volumes. In this form the magazines made such an attractive World's Fair picture-book that one set was added to the collection of volumes in the artroom of the Chicago Public Library.

A distinct literary flavor was to be found in the printed material on the pages containing the smaller illustrations. This was due to the fact that Mr. John McGovern was the editor. Of an ebullient, imaginative turn of mind, a reader who has roamed over many fields of world-lore and literature, Mr. McGovern was spurred to most characteristic endeavors by the spirit of the World's Fair times, when all the currents of thought ran large. Having graduated into newspaper work and letters from the printer's case, he had written ten volumes of essays, poems. and novels. All of these had been published at Chicago. And some of the exposition directors who had been patrons of these productions had urged him to take the editorship of Halligan's Illustrated World's Fair. Always an advocate of "western literature," he spoke of editor and publisher as "western men," and 
announced that they would "strive to do their work in their own way, aping no fashion of any other region." Declaring that "original literature is original literature," and that "the fleeting, capricious thoughts of a creator lie betewen him and the Great Creator," Mr. McGovern made the following signed statement concerning the contributions literary men might send him: "I will not edit their copy. This pledge I kept sacred in The Current; it will not be more difficult to make it more sacred in maturer years." Although asking for "a pleasant godspeed for Western Literature," Mr. McGovern voiced the larger outlook, calling attention to the fact that the Fair was not Chicago's, but the world's, and declaring that the journal was to have dignity and "to perfect a proper subjective."

Literary material of more interest from the ideas in the subject-matter than from form of presentation was the result of this policy. An excellent little poem on some theme suggested by thoughts of Christopher Columbus appeared in nearly every number. For instance, "A Mother's Song in Spain, A. D. I493," was contributed by William S. Lord, an Evanston business man who has done some writing and independent publishing from time to time. E. Hough, Ernest McGaffey, and Charles Eugene Banks were among those who wrote Columbus verses for the Illustrated World's Fair. Opie Read, of whom Mr. McGovern is an intimate friend, contributed a sketch entitled "Old Billy at the World's Fair." The literary ministers, David Swing, Robert McIntyre, and W. T. Meloy, wrote many essays for the journal, and Colonel Robert G. Ingersoll supplied an article captioned "The Effect of the World's Fair on Human Progress." A total of ninety-nine contributors was listed. While many were Chicago men, not a few in the list were residents of other places in America, and some, including Alphonse Daudet, of distant countries. In all the contributions and editorials the western element was illuminated with league-like leaps of the imagination, showing appreciation of historic perspective.

A general world's magazine was expected to be the outgrowth of Halligan's Illustrated World's Fair. In the Decem- 
ber, I893, number the publisher announced that the name of the magazine would thereafter be the Illustrated World, to be a literary journal containing "the larger views of the earth's surface." But that number was the last. Mr. Halligan lost some $\$ 30,000$ in the Illustrated World's Fair venture. The cost of the extra-large half-tones was too great to be easily met with receipts from subscriptions at $\$ 2.50$ a year, and the expense for the half-tones used in the advertising pages was so heavy that every increase in advertising meant an increase in the net loss. The republication of the numbers for sale in bound volumes did not meet with a large demand. Special patronage in some form was needed.

A fight for special support from the exposition directorate was lost by Mr. Halligan. Unfortunately for him, between I89o, when his promotion number, copyrighted as Halligan's Illustrated World's Fair, made its appearance, and the opening of the Fair in 1893, the official name adopted for it was World's Columbian Exposition" instead of "World's Fair," the name originally contemplated. Hence, although the exposition was generally spoken of as the "World's Fair," the name of his magazine would not have been correct for an official organ.

In the meantime, a monthly designated the World's Columbian Exposition Illustrated was started, in February, I89I, by Mr. James B. Campbell, a Chicago man in the printing business. A collection of old copies of the Historical Society library shows that this, too, was an excellent illustrated journal, although not so large nor so artistic as Halligan's. But Mr. Campbell succeeded in securing official support. His paper became the organ of the exposition directors, publishing official documents. It was consequently profitable to the publisher. The magazine also was declared to be the prize history of the exposition and was awarded a first premium.

Besides stating that he proposed to make the World's Columbian Exposition Illustrated a "complete encyclopedia of the great enterprise," the editor and publisher said: "In addition we will devote a proper amount of space to the art and literature of 
the day." A standing sub-line to the title made the same promise. The journal's pages, however, contained nothing of æsthetic interest except the pictorial display. The World's Columbian Exposition Illustrated ran as such until February, I894.

Out of it grew an illustrated monthly magazine which has endured until the present day. This is called Campbell's Illustrated Journal. In the number before its change of name an announcement said that in the future the magazine would devote much space to art. In it, however, chief attention has been paid to the various expositions which have followed that of 1893 in America and abroad. In I900 Mr. Campbell received a gold medal at the Paris exposition. Today his journal is advertised as a high-class illustrated magazine for home reading. But it has never been given a strong literary character, although it has been so conducted as to be a successful business enterprise.

The Graphic, which rose on the World's Fair wave, was broader in scope, and higher in artistic and literary quality, than either of the illustrated papers nominated as exposition journals. It was published by Mr. G. P. Engelhard, who is today a successful publisher of medical books. During two of the years of its existence it was edited by Mr. J. A. Spencer Dickerson, now publisher of the Baptist paper, the Standard.

Although the Graphic was a national news and general literary weekly, it grew out of a local suburban newspaper owned by Mr. Engelhard. This paper was published in Hyde Park, the suburb in which the grounds for the then projected fair were located. When Hyde Park was annexed to Chicago in I890, Mr. Engelhard converted his paper for local items into a national illustrated weekly of most general character. At one long jump this change was made, in the hope that, from a start which illustrating the World's Fair was expected to give the Graphic, a permanent foothold for a nation-wide circulation would be secured. When, in 1892, the Graphic absorbed America, which on its part had absorbed the Current, the new journal possessed whatever remnants of strength there were left from all the 
last preceding ephemeral periodicals of merit published in Chicago.

While the Graphic was a general newspaper, containing editorial reviews of independent Republican leaning, literary material of interest because of its form made up a considerable share of its contents. There was serial and briefer fiction, also some poetry, in every week's issue. Mary Hartwell Catherwood, whose romances have received general recognition, contributed a continued story of Canadian life entitled "The Children of Ha Ha Bay." The first ambitious work of Vance Thompson whose character sketches have made his name well known to magazine readers, was done for the Graphic. Florence Wilkinson, who writes verses for the leading magazines, had her first experience in writing for a periodical while serving as one of its editors. Thus, like other short-lived literary journals in Chicago, the Graphic was a training-ground for some of those entering the literary lists.

This bringing-out of local talent was even more marked in reference to illustrators. The illustrations of the Graphic were not confined, like those of the avowedly World's Fair journals, to reproductions of photographs. Every piece of fiction was enlivened with original illustrations. Decorative borders illuminated the pages. T. Dart Walker and Henry Reuterdahl, illustrators now in New York, did some of their initial magazine work for the Graphic. Will Bradley, an artist also now of New York, did borders and headpieces for it. Others who later went from Chicago to "Gotham" were discovered by this Chicago illustrated periodical.

For the reproductions of photographs which were a stable feature of the Graphic, at first zinc etchings, showing only lines, were used. But in I893 the new half-tones, capable of making shadings show in printer's ink by means of etching the dotted surfaces of copper plates were adopted. They were especially good for picturing the white buildings and dark crowds of the fair. But the process was then expensive. Mr. Engelhard had to pay 40 cents a square inch for half-tones-a high price compared with the $12 \mathrm{I} / 2$ cents charged today. 
The yearly subscription price was put at $\$ 4$. Nevertheless, the magazine attained a bona fide circulation of $\mathrm{I} 3,000$; the advertisers' annuals quoted it at 40,000; and advertising was received in such amounts that for one twelve-month period the Graphic's books showed a profit of $\$ 10,000$, although that was not enough to offset the losses of earlier years.

Then came the panic of $\mathrm{I} 893$, which during the height of the Fair business men had felt to be impending. The circulation of the Graphic dropped 50 per cent., throwing what had been a favorable balance to the other side. Its publication was soon after suspended. Interviewed for this historical sketch, Mr. Engelhard said:

The Graphic, would have lived through this reverse if it had been started in New York, for two reasons: First, because New York is the home of great successes in higher-class journalism. With a showing like that which the Graphic had made here, if made there, scores of men of wealth would have been ready to step in and keep it going as a business investment. Second, because of the aggregation of art talent and literary talent in New York. All we had here was what we discovered and created. The thing that makes the New York magazines today is not that the people of the country care particularly to patronize New York, but that the talent is there. New York is distinctly the utilitarian art center, just as Battle Creek is the national center for sanitaria and health foods, and Detriot for medical supplies. When certain interests once secure lodgment in a locality, they find a natural development along easiest lines in that place. Men of talent for illustrating, discovered by the Art Institute, daily newspapers, and short-lived magazines of Chicago, naturally migrate to New York. It was so with those who did work for the Graphic.

The names of two other illustrated periodicals, recorded as having originated in 1892 , the year in which it was first intended the World's Fair should be opened, appear in the newspaper annual lists of Chicago. One was the Illustrated Sun, a weekly appearing on Saturdays for a year. The other was the American Illustrated, a monthly of magazine form, devoted to literature and education. Its name appeared in the annuals as late as I90I, when it announced a sworn circulation of I00,000.

Puck, one of the well-established New York humorous weeklies, was published at the Columbian Exposition grounds in Chicago from May I to October I, I893. It bore the name World's 
Fair Puck, and also a Chicago post-office entry for thirty-six numbers, but its nature was not changed. There was merely a summer's variation in the subject-matter. The scenes and characters for the illustrated jokes and sketches were taken from the Fair. A frequent trick of the caricaturists and cartoonists for the World's Fair Puck was to make the exposition statutory appear animated. Incidentally, through receiving visitors at a temporary Puck Building at the Fair, the publishers pushed their circulation.

A weekly printed for the most part from plates prepared by a syndicate of New York men interested in Life, was issued in Chicago beginning in I89o. Figaro was its name. A sketch of "Figaro en Masque" - a satanic figure in pen and ink, a photograph of some Chicago society leader, and a border in brilliant red ink combine to awaken interest in the cover of each of the numbers to be found in a file at the Newberry Library. In the contents the plate matter from Life was supplemented with original material concerning the drama, society, and local affairs in Chicago, as satirically seen through a monocle like Life's. After the first year the general jokes from New York were dropped out. By $\mathrm{r} 893$ the many functions for visiting princes afforded more society news than there had been in Chicago before, and although a few tales were published in the paper, it became distinctly a society weekly. After several changes in management, with the issue of December 21, 1893, Figaro vanished from the periodical stage in Chicago.

Titles with Columbian Exposition connotation were given to two ephemeral weeklies of the literary class. One called Columbia, a Saturday paper listed in the newspaper directories as "literary," lasted for a year or so in I890 and I89I. The Columbian, catalogued as a periodical devoted to fiction, lived as brief a time in 1892 and 1893 .

A creditable quarterly designated the Queen Isabella Journal, and intended to be but ephemeral, was published in 1893 by the Queen Isabella Association to promote the interests of women at the World's Fair.

The creation of several art magazines for general readers 
was one of the direct results of the exaltation of the fine arts in Chicago and the Middle West by the World's Columbian Exposition. They grew out of the general increase in attention to the so-called fine arts-the expressions of beauty in the graphic and plastic media-which was given a much greater impetus by the Exposition than was activity in other forms of expressing the æsthetic interest. This attention was not ended with the passing of the rich collection of paintings, drawings, and sculpture in the Art Building of staff at the Fair grounds. There was a permanent result more influential locally, and from which art magazines emanated more directly. The impressive and beautiful structure of the Art Institute of Chicago, standing on the Lake Front border of the city's business maelstrom, was erected in I892. The World's Fair commissioners and the Art Institute trustees built it and gave it to the municipality. It was temporarily used for Columbian Exposition congresses. But the monumental structure of blue-gray stone, its architecture of the Italian Renaissance style, with details in classic Ionic and Corinthian, was erected on such a scale as would fit it to stand as a permanent shrine, where worshipers of the fine arts might gather in its museums and grow in appreciation of beauty, and where those with creative ability might assemble in its studios and learn technique. The art magazines which accompanied the general interest in fine arts awakened by the exposition, and the permanent establishment of this institution of art, did not depend primarily on literary form for their appeal to the æsthetic interest. But since the art of letters is furthered by the parallel increase of interest in painting and sculpture, the growth in this phase of the æsthetic interest, and the magazines which went with it, are to be considered in giving an account of the literary interests of Chicago.

Brush and Pencil is the name which two artistic magazines started at the Art Institute have borne, one of them, a general art magazine which has broken the local bounds, being still published regularly. In October, I892, the first magazine of that name was attempted at the Institute. It lived but a short time, and was soon absorbed by Arts for America. 
This more lasting magazine-Arts for America-was also established in I892, but with offices outside of the Art Institute. It was broader in its scope, and more directly the result of the general interest in fine arts created by the Exposition exhibits. One of its early objects was announced to be the reproduction of the pictures at the World's Fair. Devoted exclusively to information about the fine arts, it was an attractive monthly, dignified in tone, and, from its illustrations, beautiful in appearance. It was the organ of the Central Art Association, and was continued for nine years. Later numbers announced that one of its objects was the promotion of national art education. In I899, from an office of publication in the Auditorium tower, the magazine went out to $I_{5}, 000$ readers, largely in the north central states. Mrs. T. Vernette Morse was its editor.

The Brush and Pencil, which has been continued monthly to the present time, was begun in I897. It was started as a magazine "devoted to the interests of the students of the Art Institute." In the initial number the editor of Arts for America was thanked for the permission to revive the name Brush and Pencil. Charles Francis Browne, the painter, a member of the Art Institute corps of teachers, was the first editor of the journal. In tone it was at the beginning very much like any school or college paper.

In I900 Brush and Pencil became a general art magazine, the local elements being eliminated. During that year it was purchased by Mr. Frederick W. Morton, a former Unitarian minister, who for five months in 1899 had attempted, at Chicago, the publication of Friday, "a weekly journal of views, reviews, and piquant comment." Mr. Morton became sole editor and publisher of Brush and Pencil. For several years the office of publication was in the McClurg Building.

The character of the magazine, as a portrayer of contemporary work in the fine arts, has been excellent. The reproductions of the best of the paintings, mural decoration, and sculpture of America, Europe, and Japan, printed in its pages, have been well done. Mr. Morton holds that at no city can engraving and printing of high quality be secured more economically than in Chicago. The magazine's articles on art subjects have also been uniformly good. 
Brush and Pencil has had a circulation of I0,000, the subscribers being scattered through all the states. But Mr. Morton complains that the people of Chicago are not yet interested in art in general, that their art interest is confined to supporting the Art Institute. The magazine has not enjoyed a very prosperous business career. From July to December, 1904, its publication was temporarily discontinued, but thereafter resumed. To secure advertising, on May I, I905, the main office of the periodical was removed to New York, although the Chicago post-office entry has been retained and the mechanical work continued here. Mr. Morton says :

New York is the magazine center of the country. Any Chicago magazine that has made good its foothold has gone to New York. In New York in five days I secured $\$ 2,400$ worth of cash advertising. In Chicago I could not get that much for Brush and Pencil in five weeks.

Great Pictures, a monthly filled with reproductions of paintings by world-masters, was brought out regularly during the year I899. Its contents were confined to copies of the nude. Its file shows that it was plainly erotic, and that the periodical was designed for a perverted use of the art interests. It was published by "The White City Art Company," and was a medium for advertising the sale of single copies of the pictures reproduced in its pages.

Nature and Art, a children's monthly of æsthetic interest derived from illustrations well executed in printed colors, was begun in 1897 as Birds in Natural Colors, and continued until I90I.

Child Garden of Story, Song and Play, a monthly magazine for children of the age for primers, was established in 1892 and is still published. It is a kindergarten magazine in which the attractiveness of stories, rhymes, and pictures is utilized to educate little ones without the appearance of didactic effort, according to the principles of the "new education." It is published at the Pestalozzi-Froebel Press in Chicago, and has a circulation of 10,000 .

A unique order of literary periodicals, toned to the temper of the artist, whatever his working medium, flourished in Chi- 
cago during the years immediately following the World's Fair. The presence of a growing group of professional artists and literary workers-an artist class-and an increase in the number of dilettantes account, in part, for the interest in this type of literary medium at Chicago. Enthusiasm for individual expression, and contempt for the inartistic, gave a tone to these miniature magazines. The Chap-Book, whose history has significance in a certain line of literary and periodical publishing development for the entire country, east as well as west, was the first and most notable of this class of literary media. Others at Chicago in the nineties were Four O'Clock, the Blue Sky, and the Scroll.

Before being transplanted to Chicago, in August, I894, the Chap-Book had been issued for three months at Cambridge, Mass. Mr. Herbert S. Stone, a Harvard college man from Chicago, the son of Mr. Melville E. Stone, the journalist, was the chief originator and principal editor and publisher of the ChapBook until its hundredth and last number appeared July I 5 . I 898. As an undergraduate he had been editor of the Harvard Crimson, had contributed sketches to the Lampoon, and had prepared a serious work of First Editions of American Authors, designed for collectors. In the autumn of his senior year, I89394, at Cambridge, Mr. Stone had, with H. I. Kimball, established the firm of Stone \& Kimball, for carrying on a small bookpublishing business, which was later continued in New York by Mr. Kimball.

The periodical was put out to be an adjunct to this business. The ambitious undergraduate book-publishers needed a circular with which to advertise the books of fiction and verse bearing their imprint, and economy was to be exercised in having it circulated as second-class mail matter. Choosing a name which originated in the literary developments of England in the seventeenth century, when small tracts or booklets containing ballads and stories of heroes, hobgoblins, and witches were issued intermittently, and were sold cheap, by chapmen or peddlers, they called their circular the Chap-Book-a name which proved admirably pat for the Cambridge-Chicago pubilcation. This was 
the first chap-book to appear at stated intervals. Coming out semi-monthly, it was sold at five cents a copy and one dollar a year. It was very small and of the bibelot shape, something new at the time, and a means of emphasizing its unique character.

But for this "miscellany and review of belles-lettres" to fulfil the post-office regulations, reading-matter containing general information was required, and the title-page, which, like every other of its pages, was odd from being printed in red as well as black ink, contained these words :

The Chap-Book, Being a miscellany of curious and interesting songs, ballads, tales, histories, etc.; adorned with a variety of pictures and very delightful to read, newly composed by MANY CELEBRATED WRITERS; to which is annexed a large collection of notices of books.

In the character creation, during the first two months of the periodical, Mr. Stone was assisted by Bliss Carman, the poet. Together they wrote some original notes and essays, and edited the contributions. Sharp remarks about new books, reviews containing views framed solely from the feelings of the one who happened to write each critique, gave the Chap-Book its keynote. All of the notes were in the first person and signed. The essays, stories, and poems published, were marked by the most distinct individuality and originality. In making their bow, the chapmen of 1894 had added a word that contributions from writers "unknown" as well as from those "wellknown" would be printed. Both men who had written before and men who had never written for publication, but thought that they could do so, at once saw in the Chap-Book a medium for their freest expression. They soared in freedom from the commercial chains of the established publishers who judge literary output by the standard of the conventional demands made by the book- and magazine-buying public. The independence of the Chap-Book was emphasized by the fact that Mr. Stone and Mr. Kimball continued their publishing despite a threat from the Harvard faculty that if it was not discontinued they could not be graduated.

This new periodical, so novel in character, leaped into instant popularity with its first numbers. Such a reception took 
the young publishers by surprise. It seemed to them an accident. They, however, grasped the situation and pushed their effort with enthusiasm. Before the three months of its publication at Cambridge had ended, the Chap-Book had found an audience and was to be seen regularly on the news-stands not only of Boston and the East, but throughout the country.

The local situation was not very encouraging for the ChapBook, when in the summer of 1894 its publishing headquarters were removed to Chicago. It became a Chicago publication for the greater part of its existence chiefly through the accident that Mr. Stone's home was here, and that for personal and social reasons he decided, upon graduation from college, to carry on a professional and business career as a publisher in this city. $\mathrm{Mr}$. Harrison Garfield Rhodes, a Cleveland man, came with him to be associate editor of the Chap-Book. Mr. Stone found the residents of Chicago suffering under a reaction which came after the World's Fair. Mr. Stone says that an avalanche of criticism from discerning visitors here the year before to see the "White City" had temporarily overwhelmed the thinking people of the smokecovered, overgrown business town, which stood out unfavorably by contrast with the beautiful Fair. But he was nevertheless firm in the belief that an essentially cosmopolitan magazine could be published successfully in Chicago and the West.

Attention to new and curious developments in foreign artistic groups, particularly among the men of letters in England, which had been one of the unique features of the Chap-Book in its earliest issues, was continued and increased. Mr. Stone was in close touch with Aubrey Beardsley and the "Yellow Book" coterie of London, and from time to time made trips to London and Paris in quest of manuscripts. In a partial summary of authors who sent contributions from abroad, the following were listed:

From England: William Sharp, Edmund Gosse, Kenneth Grahame,I. Zangwill, John Davidson, "Q", William Ernest Henley, Robert Louis Stevenson, H. B. Marriott Watson, William Canton, Norman Gale, Max Beerbohm, F. Frankfort Moore, Arthur Morrison, H. G. Wells, S. Levett Yeats, Katherine Tynan Hinkson, W. B. Yeats, Thomas Hardy, E. F. Benson, William Watson, Henry Newbolt, and Andrew Lang. From France: Paul Verlaine, among others. 
Among American contributors were:

Thomas Bailey Aldrich, Alice Brown, Gertrude Hall, Richard Hovey, Louise Chandler Moulton, Gilbert Parker, Charles G. D. Roberts, Clinton Scollard, Louise Imogen Guiney, Thomas Wentworth Higginson, Maria Louise Pool, Richard Henry Stoddard, Richard Burton, Madison Cawein, Eugene Field, Julian Hawthorne, H. H. Boyesen, Clyde Fitch, Wallace Rice, Hamlin Garland, Hamilton Wright Mabie, Maurice Thompson, John Vance Cheney, Lillian Bell, John Burroughs, Stephen Crane, John Fox, Jr., Henry James, Clinton Ross, Charles F. Lummis, Edmund Clarence Stedman, George W. Cable, Alice Morse Earle, Brander Matthews, Octave Thanet, Tudor Jenks, Joseph Pennell, Kate Douglas Wiggin, Paul Laurence Dunbar, J. J. Piatt, Ruth McEnery Stuart, George Edward Woodberry, R. W. Chambers, L. E. Gates, John Jay Chapman, Norman Hapgood, Gerald Stanley Lee, John Kendrick Bangs, and Joel Chandler Harris.

That their writings would find place alongside of those of such a company from America and England was a spur to ambitious young writers in Chicago and the West, who found in the Chap-Book a medium which was suited to the virility and independence of their westernism, but at the same time was so cosmopolitan an exponent of literary expression from various parts of the world as to make for the broadening of their striving toward artistic expression. Among the Americans listed above not a few did some of their first work for the Chap-Book. In Chicago Mr. Stone solicited manuscripts not only from amateur literary workers, such as Edith Wyatt then was, but also asked newspaper men to write for the Chap-Book with special attention to form of expression. Among others of whom he asked mant1scripts were George Ade and Finley Peter Dunne. Wallace Rice wrote many clever critiques for the periodical.

The artists and literary workers of Chicago, who had grown to be quite a group, well defined through World's Fair influences, were soon rallied around the Chap-Book. A series of "Chap-Book teas" drew them to Mr. Stone's publishing-office, to look at originals of drawings and manuscripts, to talk shop, and in general to promote sociability in the professional literary and art crowd. Incidentally the "Chap-Book teas," which were followed by meetings of the "Attic Club," set the copy for the meetings of the "Little Room," an organization of creative 
writers, artists, and musicians who at present gather fortnightly at a studio in the Fine Arts Building, and by the very coming together of the artist class for a social hour or two foster professional literary and artistic endeavor.

"Chap-Book posters" were one of the unique artistic products put out by the publisher of this unique magazine. These posters were sent to the news-stands, and influenced buyers of periodicals so that sales ran up as high as 50,000, and averaged 20,000. The posters were so artistic and so fantastic that they became very popular on their own account. Harper's posters, by Penfield, had previously attracted attention. But there was a rage for Chap-Book posters, and prospective readers often competed in keen bidding for them without buying the periodical they were intended to advertise. Through making many of these posters, Will Bradley helped himself toward achieving a national reputation.

But in a short time the Chap-Book no longer stood out as a unique literary periodical. The force of imitation was soon manifest. Mr. Stone says that at one time there were twenty-six imitators of it at the news-stalls. A disinterested investigator, Frederick Winthrop Faxon, of the Bulletin of Bibliography, Boston, compiled "A Bibliography of Modern Chap-Books and Their Imitators," which was first published in the journal with which he is connected, and republished in I903 as a pamphlet under the title Ephemeral Bibelots. He lists 200 such periodicals, and in his introduction says, in part:

The small artistically printed periodicals variously called Chap-Books, Ephemerals, Bibelots, Brownie Magazines, Fadazines, Magazettes, Freak Magazines, owe their origin probably to the success of The Chap-Book, which was at once in such great demand that the early numbers were soon out of print and were in demand by collectors at from twenty to fifty times their original price. All sorts of "little magazines" were soon on the news-stands, competing for a part of The Chap-Book's favor. They were, with few exceptions, easily distinguishable by their appearance as well as by their names, which were apparently carefully chosen to indicate the ephemeral character of the publication.

The motive of publication of the genuine chap-books is hard to discover. They sprang up in the most out-of-the-way spots and died young in most 
cases. Of the first generation we still have with us only the Little Journeys (December, 1894), now in its second form; Bibelot (January, I895); Philistine (June, I895); and the Philosopher (January, 1897), now in its third size.

Many of these bibelots seem to have resulted from the desire of ambitious, unknown writers to reach a supposedly large waiting public, which could not be reached through the established magazines, either because the author could not get his manuscript accepted, or because the readers he wished to reach were not among the subscribers to the older monthlies and quarterlies. This is but our humble guess as to cause of birth; but lack of support, or unwillingness on the part of the editor to be the only support, caused the untimely (?) death of the majority. In I 898 the race had almost all died off.

The Chap-Book, in a valedictory review of its career and influence, said:

Its habits of free speech produced a curious movement among the young writers of the country. There was scarcely a village or town which did not have its little individualistic pamphlet frankly imitating the form and tone of the Chap-Book.

Many moves toward getting the Chap-Book out of the class of ephemerals and into that of magazines firmly established on a sound business basis were made by Mr. Stone after settling down to his life-work as a publisher in Chicago. One such, made January I 5, I897, was the abandonment of its small form, for the regulation $7^{1 / 2} \times 4^{3 / 4}$ inch magazine size. This change robbed the magazine of an appearance which had previously attracted attention to it when it was unique, and also proclaimed the fact that the proprietor was laying more emphasis on the commercialization than on the editing of the periodical. This change did not help sales and circulation. Furthermore, by this time the Chap-Book had said so many scorching things about books brought out by every leading publishing house in America that the publishers, from whom such a journal, containing literary critiques, should naturally have received its principal advertising patronage, tabooed it. As a bid for advertisements from general magazine advertisers, still another experimental change in form was made, February I5, I898. The pages were enlarged to the $12 \times 8 \mathrm{r} / 2$ inch illustrated weekly size, and extra 
smooth paper, suitable for advertisements containing half-tones, was used. But the Chap-Book did not secure much general advertising. Mr. Stone says one reason is that it was published too far from the seat of the advertising business-New York. But a more important reason is that no effort to secure a list of annual subscribers was made. "If we had secured such a list, the Chap-Book would be alive today," says Mr. Stone. "News-stand sales fluctuate. A list is needed in order to get advertising in off-years."

The Chap-Book died July I5, I898. On that date those of its readers who were regular subscribers received a folio of farewell. This finis notice said in part:

It was not felt necessary to continue the Chap-Book longer to demonstrate that a good literary magazine could be published in the West and meet the critical approval of the country. The Chap-Book has never depended in any special way upon the West for support; indeed, it is probable that, in proportion to its size, Chicago had fewer subscribers than any other large city. But the editors believe that the critical standards of their paper have been kept as high as would have been possible either East or West. They believe that they have been consistently honest in trying to give to their public what seemed to them the best writing they could procure, whether it came from new or well-known authors. They believe, furthermore, that the Chap-Book has been the strongest protest we have had in America against the habit of promiscuous overpraise which is threatening to make the whole body of American criticism useless and stultifying.

Instead of the July 15 issue of the Chap-Book, the subscribers will receive the issue of the Dial for the same date. To this latter journal, upon an offer from its proprietors, have been transferred the subscription list, the right to the name, and the good-will of the Chap-Book. It has been consistently maintained by the Chap-Book that the Dial is in many ways the best purely critical journal in America, and it is hoped that subscribers will be pleased that their subscriptions are to be filled out in this manner.

William Morton Payne, a regular writer for the Dial, says the Chap-Book was a fad which ran its course, and that the Dial then absorbed what was left of it. He also gives the authoritative opinion that the Chap-Book was superior to any of its imitators.

Having profited by experience with the Chap-Book, Mr. Stone has been successful in publishing and editing the House 
Beautiful. This attractive monthly was one of the first meritorious periodicals currently published at Chicago, and not a trade paper, to become established on a business footing. One reason given for the suspension of the Chap-Book was that from a business point of view the time and energy which it took could be spent more profitably in attention to the other interests of Herbert S. Stone \& Co., this firm being engaged in bringing out novels and other works, and doing general publishing. In this connection Mr. Stone's firm had taken up, in September, I897, the work of publishing the House Beautiful, which however, as from the date of its beginning in December, 1896, was then edited by Eugene Clapp, a civil engineer. When Mr. Clapp went to Cuba as a lieutenant of volunteers in the summer of I898, Mr. Stone became the editor. In I90o he sold his bookpublishing interests to Mr. Melville E. Stone, Jr., his brother, and has since conducted the House Beautiful as an individual enterprise.

Avoiding the Chap-Book pitfall, the first effort of Mr. Stone has been to secure a large list of annual subscribers. In I900 the House Beautiful had 3,00o regular subscribers, and the news-stand sales averaged 4,000. In I905 the monthly circulation claimed was 40,000 , and but a small percentage of the copies went to others than regular subscribers. To offset the difficulty in securing income from advertising which arises because 75 per cent. of all general advertising is placed by agencies in New York, the subscription price has been raised from $\$ 1$ to $\$ 2$ per year. In 1904 the size of the pages was enlarged to $9 \times 12$ inches so as to provide more advertising space next to single columns of reading-matter in the back part.

The art of interior decoration in the homes of those who, while having annual incomes of $\$ 8,000$, yet are so located that they cannot often visit the metropolitan stores, the art of landscape gardening, and architecture for country houses are the topics of æsthetic interest to which the House Beautiful is devoted. It contains little or no fiction, and Mr. Stone's society proclivities show results in its character. But since he writes or rewrites much of its contents, the periodical is marked by literary touches reminiscent of the ear-marks of the Chap-Book. 
In mentioning ephemeral imitators of the Chap-Book appearing in the nineties, Mr. Faxon, in the pamphlet heretofore quoted, says :

The Debutante, The Little Cyclist, The Mermaid, and The Night-Cap were advertised to appear in Chicago, the first in April, 1895, the others in March and May, 1896, but were probably never issued.

With a suggestion in its name of the bright give-and-take of afternoon teas, Four O'Clock was conspicuous among the original magazines expressing the attitude of certain literary workers, pen-and-ink artists, and dabblers in art at Chicago in the late nineties. Its descriptive subtitle proclaimed it to be "a monthly magazine of original writings," and its motto was "Sincerity, beauty, ease, cleverness." Most of its contents were from Chicago writers. Not all were so original and clever, nor so marked by ease and beauty of style, as to be of special literary value, though some had a degree of merit. The "sincerity" was its expression of that vague spiritual quality known as the artist soul. In illustrations, however, the periodical was original and specially attractive. The reproductions of drawings, done so as to give them the effect of originals, appeared on leaves of special texture, pasted into the magazine. This device gave the periodical distinctive æsthetic values. Young artists, a majority of them students at the Art Institute, did most of this illustrating. Among the illustrators was Carl Werntz, who is now the head of the Art Academy, an independent art school in Chicago. Four O'Clock was started some time after the Chap-Book had reached the height of its career in Chicago. No. I was dated February, I897. With the seventy-first number, December I902, Four $O^{\prime}$ Clock was merged in Muse, another of the art-spirit literary periodicals, which had grown out of still another called Philharmonic. Literary workers who recall these magazines characterize them as dilettante ephemerals.

The Blue Sky Magazine, a dainty monthly booklet of letters, came regularly from a Chicago shop from August, I899, until April, I902. In both make-up and contents it was beautiful and quaint. This little magazine was a literary exponent of the new arts-and-crafts movement. It was printed at "the house of the Blue Sky Press," 4732 Kenwood Avenue, and, like the books 
which the "Skytes," as the publishers called themselves, brought out from time to time, it was hand-set and printed by hand, exyuisite in workmanship. Most of the numbers were the size of a book easily slipped into a coat pocket. It was printed on deckleedge paper, and each paragraph was indicated with a reversed P. Thomas Wood Stevens and Alden Charles Noble, poetic souls who had been schooled in the mechanical part of their craft at Armour Institute of Technology, were the Blue Sky Magazine publishers, editors, and chief contributors.

"Happy is the man who ever sees the blue sky"-so their adopted motto ran. In an announcement of back volumes of the magazine, books bound in antique boards, they gave this quotation from "The Summer Sky":

So let us mould the Spirit of our book: to bring sometimes the sound of an old chivalric song over star-strewn waters tuning the Elder elemental note to the sweetest harmonies of the New.

Throughout, the contents showed evidence of editing and writing in this spirit. Verse, short stories, mostly on archaic themes, and two departments designated "Stray Clouds" and "The Devil, His Stuff," being made up of clever literary gossip by the young editors, filled the pages. In the verse some "Formal Measures" by Mr. Stevens, and a series of stately child rhymes by Mr. Noble, received the favor of critics. Dr. Frank W. Gunsaulus, the imaginative pulpit orator who is president of the institute which the Blue Sky Magazine editors had attended, contributed some of his poetry. Among the tales was one by James Lane Allen, entitled "The Extraordinary." An essay on "The Poetry of William Morris," by Wallace Rice, and a few lines in meter, entitled "Brothers," by Mrs. Elia W. Peattie, were written for the April, 1902, number, which proved to be the last. Each of the five volumes, except the first, was beautifully illustrated with symbolic pen-and-ink drawings and hazy wash-work. Walter J. Enright and Grace M. McClure, and other Chicago artists who were then students at the Art Institute, did most of the illustrating for the periodical. Although so attractive in its way, the Blue Sky Magazine found its constituency limited to a small cult. The publishers saw "glim- 
merings of prosperity" the second year, but the magazine was merged with another short-lived Chicago periodical, Rubric, "a magazine de luxe," which the "Skytes" said in their adieu was "the only purely literary and artistic magazine whose policy was sufficiently consistent with that of the Blue Sky to allow a reasonable fusion."

The Scroll was the name of another periodical, evidently of this general artist-dilettante group, which was listed as "literary" in the newspaper annuals of 1902 and 1903, when its founding date was given as I899; but from the collections of files and the recollections of literary workers no further information about it is attainable.

All of these magazines, with the line of artist-class sentiment woven into their literary texture, may possibly be characterized in a general way as examples of l'Art Nouveau in letters.

The cosmopolitan outlook given to Chicago by the World's Columbian Exposition stood out in five or six general magazines attempted in the latter part of the nineties. In them this aspect of the social influences left by the Fair was to be seen more clearly than in the illustrated and artistic journals which were the chief crop of the period. They show that the western cosmopolitanism mentioned in the introductory paragraphs of the first in this series of papers on literary interests had been reached. The spirit of westernism retained potency, but the current idea was that cosmopolitan products could and should come out of this western center.

A title of purely cosmopolitan connotation had been given to no periodical started in Chicago in a previous decade. The most typical and significant of those with the enlarged point of view was first issued in 1896, and was named the International. It was published much longer than a majority of the ephemeral magazines of Chicago.

The first rôle which the International took on the publishing stage made it unquestionably a cosmopolite. Its pages were filled with translations-described by the magazine as "Englished"-of stories which had been published in the contemporary literary periodicals of France, Spain, Italy, Ger- 
many, Russia, Hungary, and Japan. The theory of the publisher was that the American reading public, while made familiar with the politics, crime, and superficial events of the foreign countries through the daily newspapers, has no means of knowing the literature of the nations as it grows from month to month. As the Worlds' Fair had spread before American eyes the products of the industrial arts of all peoples, so the International was to lay before them regularly the typical literary productions of the times. It was printed in regular $7 \times 10$ inch covered magazine form, and on supercalendered instead of coated paper, thus giving a medium for exceptional half-tone illustrations.

A successful organizer of an industrial trust, Mr. A. T. H. Brower, was the founder, editor, and publisher of the International. Mr. Brower had been a prosperous business man in the printing-press and type-founders' trade at Chicago for many years, and in 1892 , during the first period of the industrial consolidations, had been the promoter of the American TypeFounders' Company, which includes all the leading type-founding concerns in the country. He was its secretary and manager until I894, when he retired from active participation in its affairs, though retaining a place on the directorate. As a mature business man of the captain-of-industry type, going into magazine-publishing at Chicago, he stands out in contrast with the many young men who, without business experience and capital have undertaken to establish periodicals here. Being well supplied with capital, Mr. Brower went into the venture confident that he was prepared to see it through on a business basis. But his ambition was also spiced with local pride. A man of general culture, born in New York, but proud of his place as a Chicagoan, Mr. Brower then said, as he repeats today:

Chicago is called "Porkopolis." But there is as much culture in proportion to population here as anywhere. Chicago as well as New York ought to have successful literary magazines.

One experiment after another was tried by him in the determination to make the International successful. An entire year was taken for preliminary preparations for No. I of Vol. I. To 
secure the stories from the various nations, Mr. Brower carried on a correspondence with magazine-publishers all over the world, made arrangements under the various copyright regulations, and secured the services of skilled translators residing at different places in America. He estimated that the market for the International's presentation of foreign literary products should be found among 50,000 cultured people of this country. But only I,500 became interested enough to send annual subscriptions to the magazine. A lack of support from Chicago and the Mississippi valley was particularly discouraging to the publisher, since Dr. Albert Shaw, editor of the Review of Reviews, had told him that two-thirds of that magazine's constituency was in this section. The unique character of the International called out a sporadic circulation in nineteen nations. But that did not help much. After a year and a half the translations were discontinued. An "International Register" of Americans going abroad was next introduced as a leading feature of the magazine. This was a list of names of travelers and tourists classified by states. But the pains required for compiling it were too great to make this experiment anything but costly. Then after the SpanishAmerican War, when there were signs of interest in the Spanish tongue, a novel scheme for teaching modern languages was undertaken. Lesson in Spanish were outlined in the magazine. Graphophones and cylinders for use in a sort of mechanical conversational method of self-education were offered for sale to subscribers. But few of them, however, took interest in graphophone Spanish, and contemplated magazine lessons in German and French were not given by the International. Travel-letters written by American visitors to out-of-the-way places, and general travel-notes by the editor, were published in all stages of the experiments with the magazine. Toward its end, when the price per copy had been reduced to ten cents, Mr. Brower, in the hope of alluring the masses, inserted trashy, popular stories of a kind in which he had no personal interest.

In seeking advertising this Chicago business man found that other Chicago business men had the same sentiment he had about a Chicago magazine, but that they did not have advertising to 
place in such a medium-at least until he could show a circulation of I5,000. At one time in the first eighteen months the magazine was nearly self-supporting, and it is conceivable that if the original character derived from the translations had been maintained the International might have found a permanent place for itself. Mr. Brower sunk $\$ 10,000$ a year in it for six years, and in July, r9or, discontinued experimenting. Today he says:

To publish a literary magazine, three things are needed: business sense, literary sense, and money-and the business sense must be that of the publishing business.

The influence of the University of Chicago upon the literary interests of the city, during the fifteen years in which the university has been one of the institutions of the community, has grown to be great. At the present time it is to be seen in many directions, and is recognized as specially direct in one of the general magazines published in the city. From the day the university opened its doors, its potential influences were regarded by men down-town as including a new force for development of literary activity. In 1893, when the professors and students on its quadrangles were living in a university atmosphere vibrant with the noise of natives of foreign lands which came to the campus from beyond the fence of the Midway Plaisance, the university's unofficial sanction was sought for Current Topics, a magazine begun in that year by a promoter of certain business schemes named David Wever, who had a publishing office for the periodicals in the Masonic Temple. Mr. Wever, as both editor and publisher, endeavored to give-and, judging from the recollections of down-town literary workers, and also from those of some members of the faculties, succeeded in giving-the impression that the magazine had some sort of University of Chicago sanction. The publishing of contributions from the professors and students of the university was the method followed in giving this impression. These were articles in the more serious vein of literary criticism, and helped greatly to fill the eightyfour pages in the rather solid-appearing journal printed in the regular magazine form, and bound in a heavy blue cover. Not only contributions written especially for it, but also papers pre- 
pared for other purposes, were solicited for the magazine. One of the most notable contributions was an article on Taine by Professor Paul Shorey, Ph.D., head of the department of the Greek language and literature at the University. For a time, Dr. Edwin H. Lewis, now professor of literature at Lewis Institute, then an assistant in rhetoric on the University of Chicago faculty in the department of English, was active, not only in contributing to Current Topics, but in securing contributions for the magazine from other university men. Soon, however, it was discovered that the publisher did not carry out his agreements to pay for the contributions he readily accepted, and that the university men were being used to give prestige to a magazine which was part of an advertising device for selling pianos. The university authors discontinued contributing, and it is alleged that the man who was a magazine-publisher for a time still owes some of them for the serious work they did for his periodical. The name of the magazine was changed to the Chicago Magazine of Current Topics, and later to Chicago Magazine. It went out of existence in I895, having been published for about two years. Dr. Lewis is of the opinion that the history of Current Topics has no more significance in the consideration of the literary interests of Chicago than any advertising scheme has. It appears to have been an example of the engraftment of interests, with a considerable element of plain graft involved.

A University of Chicago student from the West, Frank Burlingame Harris, who became a Chicago newspaper man, undertook the establishing of a general magazine in I898. Mr. Harris was a friend of Opie Read, Forrest Crissey, and other literary workers in the Press Club ranks. He rejected the name $\mathrm{Ro}$ mantic Life, suggested to him for the periodical by Mr. Read, and christened it, after the lake at the southern border of the city, the Calumet, thus giving the journal a name intended to connote the western romantic sentiment. Mr. Harris started by inserting more essays than stories. But two numbers were published. Mr. Harris had undertaken the enterprise almost without capital-a lack which literary sentiment could hardly offset. Carter's Monthly was a general story magazine begun in 
I 898 by a printer named John Carter, who came to Chicago from Streator, Ill. An advertisement of Carter's Monthly, appearing in Arts for America, announced one policy in keeping with a trend in publishing during the World's Columbian Exposition decade; namely, that the magazine would contain reproductions of 192 paintings by famous masters. Opie Read permitted the use of his name as editor. A serial by John McGovern was extensively advertised. Within a few months, however. Carter dropped the stories and devoted the bulk of his space to laudatory articles concerning some of the department stores. Mr. Read says that he then endeavored to have his name removed from the head of the page containing the table of contents in the periodical, but in vain. By the end of a year, however, the local write-ups had brought Carter's Monthly to a deserved death.

Literary efforts and temperance news were used in concoction of an oddity among the periodicals put out at Chicago in the nineties. This queer paper was named the Banner of Gold. It was started with the support of several of the "old guard" of literary newspaper men belonging to the Press Club"good fellows" who in more ways than that of writing had unfortunately followed the example of "Bobbie" Burns. Having been at Dwight, Ill., under the care of Dr. Leslie E. Keeley, some of these men were enrolled as members of "The Bichloride of Gold Club of America." They conceived the idea that the reading world should be informed on the merits of Dr. Keeley's uses for bichloride of gold, and that news along this line could be best set off with sparkling gems of new literature, fresh and pure as prairie dewdrops. Further, it was expected that the journal would prove to be an outlet for the excitements of renewed literary activity. When the first weekly number appeared, February Io, I892, Charles Eugene Banks, a newspaper writer and poet, who has written a great deal of verse, some of which touches the heart like that of Riley, and also is marked by beauty in the use of word and meter, was the editor. An outpouring of rhymed enthusiasm from his pen, appearing at the top of the first column in the first number, contained the following: 
Then down with the grinning old skull of despair;

In the army of hope we're enrolled.

From ice-berg to palm-tree fling free to the air

The banner "Bichloride of Gold."

For some time the periodical was chiefly literary, and was a medium for stories and verse used by a considerable group of Chicago men engaged in a fair order of literary endeavor. Among the contributors to early numbers were Opie Read, Stanley Waterloo, George Horton, John McGovern, and William Lightfoot Visscher; and the paper secured a following among readers interested only in the part of its contents which were of a literary nature. But after a few months some of the writers who had been members of the "Bichloride of Gold Club" surrendered their membership, and the periodical, which is still published as a monthly organ for the gold-cure, lost entirely its literary admixture.

In I893, when socio-economic congresses were held in connection with the World's Fair, a magazine designed to give a popular presentation of social and political questions, but in such a form as compared with newspaper-writing that it was rated as literary, was begun. It bore the name New Occasions. The first editor, B. F. Underwood, was succeeded by Frederick Upham Adams, who is today a general magazine and newspaper syndicate writer on these subjects. In I897 New Occasions was merged in New Time, of which Mr. Adams, at Chicago, and B. O. Flower, at Boston, were the joint editors. Mr. Flower was the founder of the Arena, and had a large personal following. The July, I897, number said "Chicago-Boston" in its imprint, and mentioned a union of West and East. But in April, I 898, Mr. Flower sent his valedictory, in which he said: "For some time I have felt it impossible to perform the duties of senior editor in a manner satisfactory to myself, while living I,OOO miles from the office of publication." Mr. Adams continued editing the magazine and writing for it, particularly in opposition to the existing money system, declaring that it was his ambition "to aid in the founding of a magazine on the rock of economic truth." In June, I898, he complained that only about 
$\$ 3,200$ in small amounts, received from all over the United States, had been paid in for capital stock, and pleaded for public subscriptions, not only for the periodical, but also for its stock. However, a file in the Chicago Public Library shows no copies of a date later than the one containing that appeal.

Self-Culture and Progress, both brought out at Chicago in I895, were two literary magazines of the home-study type. which will be given further mention in the part of the next paper tracing one of the lines of development incidentaily influential in leading to the establishment of The World To-Day, the most important of the Chicago magazines of the present decade.

An unusual use of the story form in a periodical with a slight educational bias was made in Historia, a monthly magazine published in Chicago for two years prior to the financial crash of I893. Accounts from the histories of the leading nations, rewritten in romantic style for boys and girls between the ages of twelve and twenty, were printed in this periodical. Using ten noms de plume, Fred B. Cozzens, a young man who as a student at Northwestern University had been specially interested in history, and who had also done some editorial page work for an afternoon daily, performed single-handed all of the duties of contributor, editor, and publisher. There is no doubt that the general interest in history aroused by plans for the exposition commemorating the discovery of America had some influence in leading Mr. Cozzens to undertake Historia. His magazine was illustrated with zinc-etching reproductions of pictures from old histories not copyrighted, and with some sketches by John $\mathrm{T}$. McCutcheon, the cartoonist. At one time Historia had a circulation of 8,000 including many subscribers among school children who used the magazine for supplementary reading. But Mr. Cozzens possessed little capital, although he is now the proprietor of a successful type-setting business, and his credit was taken away with the failure of a bank which had backed him in the Historia venture. He turned the magazine over to a mailorder jeweler, who soon got into trouble with the postoffice department by publishing his entire catalogue in the advertising pages of the periodical. 
A visit to the World's Columbian Exposition led Claude King, the editor and publisher of Sports Afield, an interesting magazine which he had built up at Denver from a small beginning with a sportsmen's newspaper, founded in 1887 , to remove his headquarters to Chicago in I893. As a New York printer who had learned his trade while an apprentice of the Harper firm, Mr. King, ever since moving to the West, had been a faithful reader of the New York Sun. From that paper's pungent paragraphs he had gained the impression that Chicago and its World's Fair were jokes. But Mr. King, who still publishes his magazine for a constituency of about 300,000 subscribers, says that seeing Chicago and the "White City" so impressed him that he at once decided to move from a center of influence for a part of the West to the metropolis of the entire section known as the West. Sports Afield, of which half the contents are short stories of outdoor experiences designed to be purely entertaining, and half are articles on natural history and scientific subjects intended to be instructive, is a magazine well calculated to interest typical western men and boys in the towns and villages and sparsely settled localities. Although of but mediocre literary quality, its written contents, supplemented by illustrations, are of direct appeal to the æsthetic interest. Two-thirds of the magazine's revenues are derived from subscriptions, which is unusual. The circulation was built up in the old-fashioned way of personal visits by the editor. In largest part, the magazine goes to the Northwest. Mr. King makes the comment that the people of the Southwest, while having a like interest in its contents to that of those in the Northwest, are not "businessfied," are reluctant to subscribe, and when they do give subscription orders forget to remit payments.

Besides the phases of periodical publishing at Chicago in the nineties, shown in this paper, there was also a large increase in the number of papers in the mail-order grade of so-called literary periodicals. As practically all of these "family-story" papers started in the nineties still prosper, this development in that period will be treated in the paper which is to follow on the periodicals of the present decade. 
The statistics compiled for this series of papers show that 70 of the 306 literary periodicals of all types started in Chicago were begun in the World's Fair decade. Of this number, 23 per cent. were illustrated; I I per cent. were devoted to the fine arts; 9 per cent. were of the quaint and curious artist-class literary type; I9 per cent., of the unqualified literary type; 7 per cent., of the literary information variety; and 23 per cent., of the family-story grade. The percentages for those of other types were small. Twenty-nine per cent. belonged to more than one classification, especially those classed as illustrated. Those published monthly numbered 56 , and the weeklies but 9 , in contrast with $4 \mathrm{I}$ monthlies and 25 weeklies in the eighties. But many of the monthlies were in journal form, the total of weeklies and monthlies in this form being 47 , while 20 appeared in regulation magazine form. Twenty-seven of the 70 lived but a year or less, and only 9 of the number begun in the nineties are still published. 